Article

\title{
Religious Education towards Justice: What Kind of Justice Is to Be Taught in a Christian Context?
}

\author{
Monika Bobbert
}

Seminar für Moraltheologie, The University of Münster, Münster 48149, Germany; M.Bobbert@uni-muenster.de Academic Editors: Judith Könemann and James Albright

Received: 11 August 2016; Accepted: 7 February 2017; Published: 21 February 2017

\begin{abstract}
Education is a human right. It prepares human beings for life, helps to develop individual abilities and opens up social opportunities-e.g., earning one's own living. Religion interprets our human existence in connection to a transcendental dimension. Religion can also influence moral values and behavior. The Christian religion established a basis for social life, and thus deals with religious and moral justice. As the Christian faith is understood as the identity of the qualities of love of God, of your neighbor and even of your enemy, it has to look for justice in the world. Modern Christian ethics does unfold interpersonal and global justice for all people and tries to give good reasons for moral claims. Religious education in a Christian context has to answer the question of what kind of justice is to be taught and by what means justice, as a goal of education, can be reached within such a setting. This article will unfold, from an ethical point of view, what kind of knowledge and competence teachers must have and what kind of goals can be followed with regard to their pupils or students. The results of this reflection imply certain pedagogical methods and means and exclude others-although it is not possible to go more deeply into a pedagogical discussion.
\end{abstract}

Keywords: religious education; justice; ethics; Christian ethics; education goals; Option for the Poor; ethical pluralism; equality; utilitarianism; autonomy

\section{Introduction}

Education is a human right. It prepares human beings for life, helps to develop individual abilities and opens up social opportunities-e.g., earning one's own living. Religion interprets our human existence in connection to a transcendental dimension. Religion can also influence moral values and behavior. The Christian religion established a basis for social life, and thus deals with religious and moral justice. As the Christian faith is understood as the identity of the qualities of love of God, of your neighbor and even of your enemy, it has to look for justice in the world. Modern Christian ethics does unfold interpersonal and global justice for all people and tries to gives good reasons for moral claims.

Religious education in a Christian context has to answer the question of what kind of justice is to be taught and by what means justice, as a goal of education, can be reached within such a setting. This article will unfold, from an ethical point of view, what kind of knowledge and competence teachers must have and what kind of goals can be followed with regard to their pupils or students. The results of this reflection imply certain pedagogical methods and means and exclude others-although it is not possible to go more deeply into a pedagogical discussion.

\section{Christian Education towards Justice}

\subsection{General and Christian Education towards Justice: Common Fundament}

General education, as well as all religious education, is in need of ethical knowledge and competence in arguing when education towards justice in the world is intended. Good faith, good will 
or creative pedagogical means do not suffice as soon as an ethical concept is a goal of education. Justice, as an ethical norm and a virtue, addresses moral subjects acting freely and in an informed manner. There is a certain paradox as education towards justice has to presuppose morally autonomous subjects and at the same time has to foster development towards moral autonomy [1].

As justice is a very complex idea which can raise many conflicts, pupils or students must be prepared to analyze injustice and to argue for a certain idea of justice. Every religion and its theology can only give internal reasons which are not sufficient to answer questions of justice involving all people and not only persons of one's own faith.

Social justice is a major topic and goal of Christian faith and theology, especially of liberation theology. Surprisingly, there is not much literature on religious education towards justice. How can religious education deal with justice as a topic and as a goal? As justice can be understood in different ways, from an ethical perspective it is an open question as to what kind of justice is to be taught. From a pedagogical perspective, it is an open question as to how justice can be taught as a topic and as a goal.

Philosophy and theology offer a great diversity of concepts of justice [2,3]. A morally intuitional or eclectic choice is problematic, because there often is a lack of foundation and content. Reference to a principle of justice without making explicit its theoretical foundation will only allow one to form highly subjective ideas of justice. In contrast, education towards justice has to profile justice as an ethical concept and must be able to give good reasons for ethical judgments. Thus, religious education towards justice is in need of an ethical reflection of justice.

Besides, religious education has to discuss what kind of cognitive knowledge, emotional and practical competencies are intended in respect to justice and by what methods and means these goals can be reached. Whereas many empirical studies about problems of access to education and about means of teaching do exist, the theoretical discourse about the contents and justification of justice in education is in its infancy.

This article will focus on the ethical term of justice and will unfold the questions and dimensions which have to be clarified before education towards justice should start. At the same time, this article shows the specific approach of Christian Ethics to justice and social justice. With these two perspectives, religious education towards justice will hopefully deepen its theoretical basis for education towards justice. (As scientific literature on religious education towards justice from a theoretical perspective is even rarer in English-speaking than in German-speaking countries, most of the references are in German.)

\subsection{Justice as Equality in Education}

At first view, there are plenty of publications on "justice and education". Apparently, the academic discourse on this topic is led by pedagogy, political science, theology, and philosophy. (For a comprehensive German bibliography including these disciplines, see [4] (pp. 221-248). For English articles about access to education as a form of social justice, see $[5,6]$. In contrast to rare theoretical publications on justice and education, many empirical studies on problems of education and discrimination in education exist. See e.g., Autin et al. [7] and the references given.) The domains of pedagogy and philosophical ethics offer a few rather general works on "education and justice". The domain of social sciences provides extensive references. Empirically analyzing problems of injustice with regard to education, e.g., unequal access to education or forms of discrimination, these studies are mostly based on an implicit, rather than explicit comprehension of justice.

Christian ethics, and the Protestant and Catholic Churches, too, have dealt with these problems of inequality with regard to education over the past decade. These publications focus on justice in access to education. Education contributes to individual and social justice, as it is considered to be a morally highly relevant asset in democratic societies. That is because education is a means to an end-a means of self-determination, welfare, responsible lifestyle, and social participation. Essentially, education represents the precondition for concrete cognitions of any individual human right [8-10]. 
Even though their motivations may be different, the purposes of philosophical ethics and Christian ethics are the same in the case of justice in education. Clarifying reasonably what kinds of education all people are entitled to for reasons of justice and what groups require specific education due to discrimination or particular circumstances-for example, girls and women, disabled people and people with an intellectual gift, children with a migrational background, and educationally deprived children. This ethical discourse on justice and education generally presupposes every person's moral right to education. This means that all educational institutions with people in all phases of life are addressed and particular measures for disadvantaged groups have to be offered as compensation. But this article will not deal with this approach to justice with regard to education; rather, this article will focus on justice as a topic and as a goal within an educational process.

\subsection{Education towards Justice}

Thus, another, totally different field of discourse and practice is represented by the field of education towards justice, which intends to empower individuals, to improve interaction in groups in terms of justice and to make possible a commitment to social justice.

In the academic domain of general pedagogy, there are fewer publications on justice as a topic and goal of education than there are in the domain of society and politics in terms of school and adult education. Justice is often not mentioned explicitly. Instead, justice-oriented terms are discussed, such as human rights, poverty, gender issues, or issues of globalization and environment. Whenever education tends towards justice in a Christian context, it is a matter of the pedagogy of religion, pastoral ministry, and adult education. These religion-related kinds of education face up to the claim of justice within the range of one's own actions (which is the process of education) and within the range of the results (which is the addressees' ability for justice) - pertaining to individual attitudes and actions, social participation, and the commitment to human political justice. That is "education towards justice", or rather "religious education towards social justice".

However, Judith Könemann and Norbert Mette assert that the pedagogy of religion has not explicitly discussed the topic of justice for a long time [11] (p. 13). In line with the hermeneutical paradigm, it is about enabling people to make their own well-grounded decisions with respect to morality and religion. This paradigm's goal is that one understands oneself and the faith conveyed, and also that one interprets oneself and social structures bound by the claim of faith. (For these superior goals of religious education, see [12] (pp. 40-42))

Current religious pedagogical articles on justice within the range of religious education (cf. [4,13-18]) understand justice as social justice. It is thus related to the approach of liberation theology. From there, religious education has to enable concrete social responsibility, responsibility for social justice, and critique of ideology. (For these goals of religious education, see [13].) Equally, religious education has to be an instruction for a critical reflection of oneself, one's own lifestyle, and a just way of living.

Speaking of "education towards of justice" requires a determination of purpose and means of education. The dimensions and levels can be many and different. Should philosophical knowledge of justice or should appropriate abilities and capabilities be taught? Is it about doing justice in the classroom, in advanced training courses, or is it about teaching the ability to perceive concrete problems of justice and to develop proposals for solutions?

This article discusses the perspectives of justice in method and content within the range of religious education. The discourse of the pedagogy of religion on religious education towards justice, and especially its contents and purposes, will be used as the initial point. In this connection, the assumptions regarding the pedagogical or theological theories of education will not be identified or critically classified in detail $[19,20]$. The focus is on how discourses on justice are led by ethics. 


\section{Justice as an Essential Concept of Christian Ethics}

\subsection{Autonomous Morality in the Context of Christianity}

The central purpose of autonomous morality in the context of Christianity is task-oriented and bindingly normative. Besides, Christian ethics can also deal with questions of a good life and supporting virtues in the sense of Aristoteles and Thomas Aquinus-but in comparison to normative ethics, the latter dimension of ethics will not be so much in the focus of this article.

Normative ethical judgments are required to be reasonably comprehensible and generalizable. Christian ethics aims at comprising critically the premisses of (Catholic or Protestant) denomination, together with arguing on the basis of a philosophical-ethical approach. Ethically relevant experiences and knowledge of social and other sciences have to be integrated into ethical reflection. Thus, multidisciplinarity is indispensable for moral reflection in a Christian context, and so it is for issues of education and justice, too. In a pluralistic society and in a world containing various religions and cultures, this comprehension of Christian ethics and the corresponding procedure establish a search for common justice in the face of different convictions and traditions.

What kind of contribution is specific for Christian ethics? Primarily, the context of the discovery of ethical standards is attributed to theology (cf. [21,22]) —and not so much the context of justification. Hence, the Christian context is relevant for a sensitization to, and discovery of ethical issues and for the motivation to act morally. Theology implies at last a relativization of morality. In contrast to Kant, for instance, the ability of morality does not constitute personhood ultimately, but rather its need of redemption and its non-exchangeability towards God.

Theology as a science of faith can neither replace ethical arguments nor fundamentally change their contents. Thus, theology does not supersede ethical reasoning by philosophical means. However, theological motives may inspire ethical reflections or may influence the significance of ethical arguments. Also, theological and philosophical forms of thinking and arguing bear a great resemblance. Central points, such as the likeness of God (or equality of all people towards God), the non-replaceable personhood, the creaturehood (or finiteness and contingency) of a human being, his or her ability to err and make mistakes, the inevitable narrowness of life limited by death, and finally the incarnation of God and the effects of Jesus (or the Option for the Poor and Vulnerable) are as relevant for the field of education as they are anthropologically basic constitutions. Even though these points cannot replace ethical, pedagogical, and theological-systematic reflections, they still feature guidelines for issues of justice and education in the Christian context. Among other things, they present the challenge of not discriminating against human beings for contingent characteristics such as sex and gender, social environment, or nationality. These points present more of a challenge to respect the existing diversity and the non-perfection of agents, and to consider the purpose of autonomy from the point of view of the weak.

\subsection{Justice in the Field of Christian Theology}

The purpose of justice in the world is strongly linked to a theological interpretation of the Christian message. Justice in God's history with the people has continued in the history of the faithful and in the establishment of the church [23]. (Due to the article's shortness, the explanation is cursory. For a more detailed comprehension, see [24-26].) Various understandings of justice come from Biblical testimony, tradition, and Catholic social teaching. For instance, the Old Testament deals with the exterior justice of law, interior virtuousness, and social justice. In the New Testament, Jesus of Nazareth reveals the creative character of justice in contrast to that one of law. In the Sermon on the Mount, Jesus expresses the Option for the Poor. The Acts of the Apostles are given distinction by the principle of distribution of goods. The early church also perceived justice as solidarity with the poor and vulnerable. In Late Antiquity and the Middle Ages, institutions such as poorhouses, hospices, and hospitals were built to compensate for injustice. These selected examples of justice from Biblical testimony, tradition, and 
Catholic social teaching show the diversity of justice within a Christian context. Admittedly, it is not self-evident which kind of justice should be focused on in religious education.

Of God, the human being is able and entitled to detect and to realize what is just. All perceptions of justice-however different they may be-are based on the conclusion that the just distribution of goods among the People of God is equally a sign of growing into the fulfillment of promise. The experience of God and the responsibility for the world, eschatological promise and distribution of goods in the world are two sides of the same coin. But considering persons and institutions, recognizing, reasoning and acting only have preliminary and fractional character. In the light of human contingency and sin, it always requires a transforming and liberating by God.

The relationship between God and the human being correlates with social justice as the embodiment of the Christian claim in the world. The commitment to social justice as the expression of the tight connection between the experience of God and responsibility for the world is especially represented by liberation theology (cf. [27-30]). The discipleship points at the political dimension of action. Other theological approaches (for example, the idea of freedom by Schockenhoff [31]) accentuate grace and liberation by God and emphasize then individual attitude and spiritual engagement. In spite of different theological focuses in Christology, the theology of creation, the theology of grace etc., it is undeniable that the identification with suffering and injustice, as well as the Option for the Poor and Vulnerable are an essential "proprium" of Christian faith.

It is also undeniable that just institutional and political structures are a decisive condition for morally right actions and a good life [32]: From the ethical point of view, social ethical issues cannot be solved by an individual ethical approach—although responsible actions by individuals are needed to fulfill structures and to change unjust ones. Notwithstanding this relation, people may not want individual heroism from individuals in problematic institutional structures. Structures which instead promote and support responsible action have to be established.

The theological ethicist Dietmar Mieth points out that Jesus's teaching on justice has been misinterpreted as a teaching dealing with mercy for centuries. To demonstrate a corrective, he quotes Augustine's "De disciplina christiana" that construes Mt 25, 40: "Truly I tell you, whatever you did for one of the least of these brothers and sisters of mine, you did for me". Augustine emphasizes that it not only depends on helping the individual, deserving, poor person by meeting his or her basic needs, such as food, clothes, and so forth. It also depends on establishing institutions, on shaping a society in which such deserving poor and profound inequalities do not exist: "Living is better in a society of equals". The implementation of a society such as this is a matter of justice. As much as Augustine was skeptical of the earthly prospects of a "civitas terrena" (an earthly city), he was convinced that the biblical message is not to be interpreted as an ethics of convictions, but as an ethics of structures as well [23].

\subsection{Justice and Four Dimensions of Ethical Reflection}

\subsubsection{The Definition of Justice}

Justice is a basic concept of ethics and social philosophy. It names a principle that evaluates standards and attitudes which are conducive to the right and good form of living together. To apply the principle of justice, three conditions need to be clarified: the matter or the kind of goods (e.g., concrete resources such as income or abstract goods such as legitimate claims), the scope (e.g., inhabitants of a nation or the world's community; present or future generations), and standards of justice that measure the degree of fulfillment. The different standards of justice correlate with different approaches of a practical or a political philosophy: rights-based approaches in the Kantian tradition (cf. [33,34]), social contract theories (cf. [35]), utilitarian approaches (cf. [36]), approaches in the Aristotelian tradition, and libertarian approaches (cf. [37]). These prominent, but divergent approaches to justice will be displayed later in this text. 
In modern ethics, there are four dimensions of morality to consider and to convey jointly for an ethical reflection of a field of practice. With regard to justice and to teaching justice in religious education, these four dimensions are to be distinguished and fulfilled specifically.

\subsubsection{Ethics of Ambition and Normative Ethics}

Ethics of the good life, or ethics of ambition, is geared to individual success in life and a good life together in society. Since antiquity, justice has been regarded as a cardinal virtue alongside prudence, courage, and temperance. At the same time, it has been regarded as a whole of virtues: justice is the measure and mean, the equivalence and balance of forces and virtues of the soul [38] (p. 424). Therefore, justice as a virtue is related to self-fulfillment as well as related to other people. By the ethics of ambitions dealing with virtues or attitudes, and also dealing with models of human experiences and moral concepts, it is ethics in a broader sense with a recommendatory character.

In contrast, normative ethics deals with the interests and moral rights of other people. As it analyzes actions in terms of justifiable claims of other people, normative ethics is ethics in a narrower sense. Normative ethics deals with the moral rightness of individual action, and the rightness of institutions and their rules and structures. Those claims that are often perceived as moral rights and responsibilities and identified as justified take equal account of all people, so that they have to be obeyed unconditionally. Hence, this binding character is categorical which means it is superordinate in comparison to any other claim. Normative ethics, then, has a mandatory character, and according, justice as equality or justice as inequality is discussed by indicating criteria of distribution.

\subsubsection{Individual and Social Ethics}

The two dimensions of ethics named above can also be looked at from an individual ethical and a social ethical view. Individual ethics foregrounds individuals, their actions, and their schemes of life. It explains morally right actions or ideas of a "good life". Thus, individual ethics points out what rights accrue to whom and what rights have to be respected by others. Additionally, it deals with the question of a good conduct of life. In contrast, social ethics focusses on institutions, their structures and rules since they shape individual actions and life together in society.

\subsubsection{Four Dimensions of Ethical Reflection Being Related to Each Other}

An extensive comprehension of ethics - ethics of ambition, normative ethics, individual and social ethics-is helpful for an ethical reflection. The four dimensions represent an instrument for ascertaining the issues. Ascertaining systematically a field of practice such as education (according to the four dimensions) contributes a better identification and analysis of complex issues of justice. Imprecise and narrow interpretations are avoided by minding not only the actions of the persons involved, but also the structural factors when searching for the causes. Additionally, the four dimensions may serve as an instrument of contextualization.

If education's focus is enabling one to fulfill oneself, for instance, one has to deal with the dimension of individual or social ethics of a good life and a good life together, which is the dimension of ethics of ambition. It can be said that one does and is done justice whenever-with the aid of a personal educational programme-one is able to live up to one's desires and capabilities for shaping one's own identity. Justice, then, is understood to be the promotion of difference and individuality.

The ethical-normative level and the social ethical dimension could also be referred to, if specific kinds of education were seen as premisses for any individual's self-fulfillment and if an assurance of these institutional premisses was claimed. It is an ethical-normative question as to what kind and what minimum of self-fulfillment any person is morally entitled to. Justice then means equality.

If education is deemed to be a general means for the supply and implementation of basic moral rights and responsibilities, education then has to be available for everyone, for this rational reason of purpose alone. Whether a specific kind of education is required and when the premisses for the basic moral rights and responsibilities are fulfilled, need to be clarified in advance. From that point, 
for example, the moral right to self-determination, health protection, income, and even the right to physical and psychic integrity without education cannot, or at least can hardly, be heeded. Normative individual ethics and, even more so, normative social ethics have to postulate education, as a society has to allocate necessary structures and institutions to its members.

Partially, it is emphasized that education as a means contributes to justice of participation. If social participation shall only be deemed to be the issue of a good life, education may then be one way out of many to achieve this. But usually social participation is regarded as a basic moral right of any person. Hence, the ethical-normative question is what kind of, and how much, education is required to realize the right to social participation. If specific groups in society are disadvantaged in having access to education due to characteristics such as sex/gender, ethnicity, disability, or family background, measures of compensation and aid are required. These measures are assigned to social ethics.

Education is a means to welfare and the advancement of society. Is that why all society members have to be educated? Is there eventually a responsibility for education to serve the welfare of society? This is a matter of ethical-normative issues. Also, it could be an issue on the good life together in society with a recommendatory character. Finally, it can be discussed whether one who has been successfully educated is responsible for providing his or her education to others, or whether it is a question of a good life if one shares with others one's knowledge and capabilities.

Modern ethics considers justice primarily as an ethical-normative concept. Anyhow, there are ambitious ethical understandings of justice as a virtue. One could say: Seeking and cultivating the so-called cardinal virtues of justice contributes to a successful life. This means that a just person instills respect and trust, or a good life together in society can be shaped by a "culture of justice". In comparison to individual ethics and the ethics of ambition, social ethics and its task of finding criteria for just institutions certainly has a priority in modern society. Moral heroism can be avoided by good and right structures and institutions [23] (p. 12).

\section{Religious Education towards Justice and Education Goals}

As education shapes individuals in a processual way and thus characterizes a becoming, it necessarily contains intentional goods of education or determinations of purpose. In contrast to general education, religious education towards justice is a special education through which various education aims can be provided for. When education, for example, is geared to justice, there are different kinds of interdependencies, not only depending on the comprehension of justice, but also on a particular theory of education and its own educational goals. In the field of pedagogy and adult education, there are strong controversies over philosophical, empirical, historic-humanistically and socially critical theories and terms of education which cannot be discussed in this article. Besides, if justice is the topic and goal of education, it is clear, that a morally responsible, thus morally autonomous subject has to understand and to accept the overall goal and also the overall presupposition of any educational process. (For the ambivalence of presupposing and intending autonomy of pupils and students in educational processes, see [1].)

Nevertheless, in the face of the ambiguity of the term education, three general aspects characterizing educational goals will be considered below. According to the Aristotelian theory of action that distinguishes between theoretical, practical, and poietic actions, educational goals can be seen as qualifications of knowledge, morality, and artistic and technical skills. Between these goals, there is an interdependency which implies a hierarchy. The general education goals mentioned will be related to justice as a justified ethical norm, justice as a virtue or attitude, and capabilities with regard to justice to reach just results in practice.

\subsection{Education Goals under Theoretical Aspects}

In the view of general education, the question is about the basic theoretical position in terms of a holistic "weltanschauung". Kant's questions adumbrate that: "What can I know? What should I do? What may I hope? What is the human being?" An educational concept and a pedagogy that only 
concentrate on the first question are deficient [19] (p. 26). (An author's note: The social superiority of the scientific-pragmatic paradigm currently reduces the claim of general education.) In the field of justice, religious education as a kind of specific education focuses on specific knowledge, such as concepts, methods, and theories that are found among theology, philosophy, law, economics, and social sciences. For an analysis of concrete justice issues, an interdisciplinary method is indispensable. For instance, to fulfill the "Christian Option for the Poor", theology has to show how it arrives at this option. If it is about concrete action and responsibility for the world, the following ethical perspective has to clarify what people are entitled to, what identifies people as "poor", and by what means their situation could be improved. This established concept of poverty has to be operationalized by political and economic sciences to obtain an empirically useful definition of poverty. Poverty can, for example, be seen as a lack of resources (e.g., income, health), as a lack of opportunities (e.g., access to education) or as a lack of capabilities (e.g., social competence). (See e.g., $[39,40]$.) Poverty can be measured absolutely or relatively. Besides, whether poverty is seen as self-inflicted or as the result of structural injustice is very decisive. On a normative level, claims may be made of abolishing poverty by social redistribution or by self-achievement. To analyze poverty's causes and to develop approaches to solutions, theories and the empirical methods of social sciences have to be accessed. (See for empirical methods and presumptions of measuring poverty [41].) Finally, the question of concrete actions and institutions returns: who has what kind of possible courses of action and who is in charge of what? To be clear about what are the normative debates and what kind of arguments stand for a certain position, philosophical and theological ethics has to be consulted by experts of education.

\subsection{Education Goals under Practical Aspects}

Within the moral meaning of the "good life" in the Aristotelian tradition, the practical aspect deals with moral perfection, i.e., a morally stable attitude which is expressed by the responsible realization of a good life. Education has to provide the ability for free creation and for moral reflection to succeed in one's own life and in living together. (cf. e.g., [42].) Virtues or attitudes of individuals can also be relevant for acting ethically right in the sense of normative ethics according to Kant or Bentham. Teaching a critical facility is important, considering any one person's condition of guilt and "structural sins", such as general conditions and structures of immorality (in view of general education, guilt is primarily understood as a term of moral philosophy and a judicial term; in the view of religious education below, guilt is used in a religious sense). Abilities to realize the "ought" have to be established.

Asking existential questions and construing oneself under the claim of faith are important goals of religious education [12] (pp. 41-42). If education aims at the ability for a successful conduct of life, one has to fulfill oneself and also to practice the attitude of justice. If education aims at social justice, one has to relate oneself responsibly to others; one has to develop moral ability to judge in view of justice, and to be willing to realize justice. Pedagogical, psychological, and sociological theories of moral development and capacity for judgment have to be adopted and then utilized for pedagogical and didactical issues. Religious education on human rights can sensitize people to human rights abuse and (by consulting other disciplines) to the cognition of complex correlations. Consequently, the education goal is developing a hermeneutical expertise in understanding oneself and the world to achieve differentiated solutions [18].

\subsection{Education Goals under Poietic Aspects}

First of all, the poietic aspect means a creative producing and experiencing in terms of the Aristotelian distinction. It is a goal of general education firstly to experience the aesthetics of art and nature, and secondly to connect this experience with the practical and theoretical aspects. Specific education requires an acquisition of field-related abilities and capabilities, besides specialized knowledge. The didactical question "What concrete abilities and capabilities or in other words: what kind of techniques should be learned?" for realizing justice is implied by a poietic comprehension 
which is about creating and focusing on results, rather than performing actions. (The author deviates from Anzenbacher and refers to Höffe [43] (p. 195). But the author of this article sees the Aristotelian distinction somewhat differently than Aristotle himself meant.)

The knowledge of the criteria of justice, its reasons and the motivation for dealing justly require instrumental abilities and skills in the course of implementation. (See e.g., [44].) For instance, the ability to discern one's own needs and desires and also the needs of others is required for self-fulfillment and a responsible lifestyle. Being able to shift perspectives and being empathic are premises for a just interaction. In addition, further important premisses are the ability to conduct a non-hierarchical discourse and to achieve a non-violent and constructive conflict resolution. (For an empirical qualitative study, see [45]. Diane Vetter from Canada shows the value of classroom talks as a means of empowering students to global awareness and critical thinking with regard to social justice, equality and environmental concern. Autin et al. [7] from Switzerland have shown empirically that selection in educational institutions predicts support for (non)egalitarian assessment practices.) In conjunction with social justice, it is still important that individuals are not overextended-facing the ethical insight that an implementation of justice is presupposed by adjuvant structures and institutions.

\subsection{Education towards Justice}

It has been shown that teaching justice can follow different education goals. Although priorities will be set, it is important to recognize the interdependency of the theoretical, practical and poietic aspects. If a teacher focuses on, for example, the competence of dealing fairly and peacefully with conflicts in the classroom, then ideas of procedural justice, justice as compensation, justice as solidarity with the weak but also the justice of achievement will come up. These divergent aspects of justice should be discussed on a theoretical level instead of a level of individual or group convictions. If education towards justice intends to make people sensitive to unjust situations and global injustice, this goal will be situated on the theoretical, practical and poietic level. The urgent question will probably be by what means distant persons and nations can diminish absolute poverty in foreign countries. But teachers should also be prepared to discuss why it might be a right of poor people to be helped by others. Here, ethical approaches to justice and arguments for and against distribution of goods and opportunities will be decisive. If educators are not prepared to switch between the above mentioned three aspects of education goals as soon as they try to educate towards justice in an ethical sense, they are in danger of teaching subjective or collective moral convictions instead of ethics as the voluntary persuadedness of moral subjects.

What kind of theoretical knowledge of justice is necessary for education towards justice, will be unfolded in the following chapter.

\section{Manifold Understandings of Justice and the Necessity of Reasoned Selection}

When religious education and the pedagogy of religion try to educate towards justice, different understandings of justice are consulted. Mostly, they are resorted to on the level of normative social ethics: equality, distributive justice, equal opportunities, participatory justice and involvement, the justice of differences, poetic justice, and the justice of ability, resources, and recognition. (See the articles and bibliographies in $[4,13,46-56]$.) The subordinated and critically regarded ones are the justice of contracts and of performance. Justice of necessity, procedure, and justice in view of juridical law are rarely mentioned.

In their explanations, religious educational authors refer in their presentations on education and justice partially to an ethical approach, and partially, they give expression to their understanding of justice in the view of education without further reasoning. They seem to suppose that their definition of justice and its outlined content are shared by the majority, or at least these definitions seem to be claimed by a high reasonability. The impression is given that merely the articulation of an understanding of justice by a person or a group is sufficient. 
However, in spite of a seemingly identical term "justice", the content can be outlined differently. Also, in contrast to ethics as a reflection on morality, one would only describe the specific individual's or group's morality. Hence, one would do research in the field of empirical social sciences, moral psychology, or sociology. Ethics as a normative discipline seeks the "ought" and not the "it is" or "what people usually do". In contrast, social sciences working empirically seek the actual state. Without an ethical approach that seeks good reasons for morality, e.g., a specific understanding of justice, and that reassesses moral intuitions for proving authorities, criticism of predominating moral ideas and institutions is not possible. A concept of religious education which fosters a certain understanding of justice without giving good reasons tends to be dogmatic or fundamentalist.

In general, without an indication of good reasons, a definition of justice runs the risk of being specified at will. The moral normative standards mentioned would then only have the character of political demands. In the case of conflicts of norm-e.g., how to balance equal opportunities and the justice of performance-there would be no superior rules or other criteria of weighing up.

Every concept of religious education should make explicit its idea of justice and give reasons for preferring one selected understanding of justice. Only then is it possible to respond to questions such as the following: Is the primacy of equality justifiable? How much inequality is acceptable? What is to be expected of people to change unjust conditions and what means are legitimate? Without any preconception of justice, no issue of justice can be identified. Without a specified norm of justice, no moral normative claim of change can be raised. Moreover, it has to be clear to what field the claim of justice is related-such as the respect for specific human rights in the field of education or a redistribution of wealth. Also, it has to be clear whether this is a negative (e.g., right to not being discriminated against) or a positive right (e.g., the right to integration), where the limits of rights of justice lie (e.g., the right to qualifying offers), and in what way conflicting moral interests can be weighed up. An understanding of justice changes by being dependent on its ethical approach, for ethical norms themselves turn out differently owing to approach. Besides, the path of reasoning partially implies the existence of criteria to weigh up conflicting interests and norms. (It is similar to the principle of autonomy-see [57].)

The three ethical approaches discussed below have in common that well-founded moral-normative judgments of justice can be evolved by them. Descriptive approaches have to be distinguished from these three. They describe the subject-matter "morality" in its different aspects and manifestations and offer meta-ethical approaches that provide a conceptual basis for an academic examination of the phenomenon "morality".

\subsection{Ethical Approach to Justice: Dialectically Necessary Method to Justify Moral Rights}

The argumentation of the moral philosopher Alan Gewirth constitutes individual rights in the Kantian tradition. His results are partially similar to the Human Rights Convention of the United Nations. Instead of legal or historical justification, Gewirth offers a philosophical justification which claims to persuade every rational actor. He reasons general individual rights by showing that goods such as life, physical and mental integrity, food, accommodation, peace, and even self-esteem and the possibility to gain education and wealth, are all general necessary conditions for any kind of action. (The originator of this kind of argumentation is Kant [58], i.e., Gewirth [33] is a contemporary representative. For an overview, see [59] (pp. 77-93, 139-149).) A dialectically necessary method of the interpretations of human actions reveals the implicit conditions. The insight that we do need these goods leads inevitably—after passing through several steps of justification-to a generalizable claim that any person has the moral rights to these generically necessary conditions of action.

According to Gewirth, the following is essential for any person:

- $\quad$ Any person is an end in him- or herself and not clearable in the end. Regardless of prestige and value for others, specific generic rights are any person's due. Individual rights have to be protected, especially when the people affected cannot defend them by themselves. 
- Among the generic individual rights are the rights to life and protection of health, the right to physical and mental integrity, to equal treatment, and to prohibition of discrimination due to exterior features. The generic moral rights are to be obeyed categorically.

- Moral rights, such as the right to education or wealth, confirm the obligation for the others to help. Hence, some rights are positive rights. To avoid single agents' excessive demands and to guarantee individual rights, (social state) institutions have to be established.

With Gewirth, justice means to conform with individual moral rights and duties. Gewirth's approach is able to give a philosophical justification for human rights as we know them from European history and according to international law.

\subsection{Ethical Approach: The Hypothetical "Original Position" to Justify Two Principles of Justice}

The arguments of the political philosopher John Rawls (also following the Kantian tradition) justifies individual moral rights by a thought experiment containing a hypothetical "original position" [34]. Under the "veil of ignorance" (which means abstracting away from one's own constitution and social status), Rawls assumes that rational human beings make decisions on the distribution of rights, freedoms, opportunities, income, and wealth that a rational person wants to have according to two principles of justice [34] (pp. 81,336):

1. Each citizen is guaranteed a fully adequate scheme of basic liberties, which is compatible with the same scheme of liberties for all others;

2. Social and economic inequalities must satisfy two conditions:

a. they are to the greatest benefit of the least advantaged (the difference principle);

b. they are attached to positions and offices open to all under conditions of fair quality of opportunity.

Rawls is especially noted for his Difference Principle: only those differences can be justified which are a benefit for all members of society or rather which are the greatest benefit to the least advantaged members.

\subsection{The Empirical Pursuit of Pleasure (and Pain) Justifies the Norm of Maximizing Total Utility}

In the tradition of Jeremy Bentham, utilitarian approaches define justice by having the interests of all who are involved in an action in mind to promote and maximize the utility of the group or society. In England in the 18th century, Bentham opposed the upper classes, which were characterized by privileges, by his dictum: "Everybody to count for one, nobody for more than one" (Bentham's popular dictum is not to be found in his writings, but is quoted by Mill [60] (p. 108).), to increase the general welfare. Facing the empirical fact that people long for pleasure and avoid pain, Bentham established the moral norm that actions have to be chosen, the consequences of which lead to the greatest amount of happiness of the greatest number. Utilitarian approaches (they belong to moral normative ethics) arrive at the following conclusion: (The originator of this path of argumentation is Bentham, i.e., Singer is a contemporary representative. For an overview, see [61].)

- A superior norm is the principle of maximizing general utility for all through actions and consequences affecting people;

- A more detailed definition of utility is left open, as Bentham's assumption that any person avoids pain and longs for pleasure, was soon criticized due to empirical inaccuracy.

The question of the characteristics of utility, its measurement and accumulation options pervades any utilitarian theory.

The Preference utilitarianism referring to the principle of utility just gives attention to rational persons and entails promoting actions that fulfill the interests (or preferences) of those persons being involved. This approach understands justice as the maximization of the interests of all affected persons. 


\subsection{Challenge by Ethical Pluralism of Theories}

Numerous other ethical approaches could be given to substantiate concepts of justice. (See the theories of justice considered in Section 2.3.) But still, there is none that would not be questioned on its stringency in norm foundation. In addition to that, the approaches partially conflict with each other. From the point of view that argues with undeniable moral rights and responsibilities, it is a problem to pursue the optimization of total welfare, but not the single person's welfare, since individuals or minorities might disappear then in utilities of groups. (For justice and health, see [62].) And yet, utilitarian approaches ask to what extent subsequent considerations of moral rights are not merely acceptable but required.

The controversy of reasoning justice norms cannot be solved entirely, even though struggling with good reasons and demonstrating contradictoriness or tautologies by ethical variations of cognitivism can clarify many perspectives. Methods of seeking coherence and convergence or seeking a "reflexive balance" just represent methodical compromises (cf. e.g., [63], esp. pp. 38-40; [34], esp. pp. 65-73; [64-66]).

For the exposures to the ethical pluralism of theories, there are no easy solutions. Nonetheless, it would be problematic whenever norms of justice are just used eclectically or due to their "matching" contents that make advances by considering personal or collective moral intuitions. Furthermore, the basic requirements can be classified as (1) expatiating on implicit concepts of justice that try to reveal injustice and develop ideas for improvement; (2) noting the necessity of foundation; and (3) complying with this necessity as far as possible. To add authority to the claim of justice, it is essential not to proceed decisionistically or tendentiously. An education towards justice that contributes freedom and the capacity of discernment to its addressees can only rely on the convincing power of better arguments and may not conceal the limits of a rational discourse.

For a Christian Ethics with central concepts such as human dignity and individuality, an approach with individual human rights and duties conforms well. But in some cases, too, the maximization of well-being of all affected persons might be ethically reasonable. A discourse on justice should be led by human moral rights, but should not exclude other arguments per se. Nevertheless, an approach to justice from a Christian perspective must not be decided in advance, if Christian ethics is serious about the claim of reasoning with philosophical means and methods.

\section{Religious Education towards Justice: Methodological Aspects}

\subsection{Necessity of Interdisciplinarity}

The mediation of justice in the field of (religious) education is referred to interdisciplinarity. An ethical judgment facing concrete problems must always access the expertise of one or more specific disciplines or professions. Their knowledge or conclusions are also based on assumptions, according to scientific theory and social frame conditions. Applied topics (such as the problem of electronic products such as smart phones and computers being produced by the acceptance of serious human rights abuses-from child labour and civil wars in connection with the production of raw materials in Africa's mines, to work conditions that equal the deficiency of the 19th century in Europe) need to involve physics and geology, economics, political science, law, ethics, and practical policy for analyzing causes and finding solutions from an ethical point of view. Clarifying what political and institutional moves could be effective comes along with the expertise and with a sense of the possibilities as well. Ethical reflections on the possible first steps and weighing up the lesser and major evil is required to clarify what people in industrialized countries ought to do to get a real fair-trade smart phone on the market [67].

\subsection{See-Judge-Act: A Hermeneutical Circle or Spiral}

"No normative concept of justice means no problem of justice". Without a preconception, without attention to and concentration on a phenomenon, there is less to spot. In the process of analyzing problems of justice and in the process of making a judgment, moral relevant presumptions or ethical 
background theories have to be indicated. (For examples, see [68].) It is imperative for questions of justice in the context of religious education and it is also necessary for empirically working scientists. The political scientist W. Merkel acted exceptionally but in an exemplar way: he not only developed five operationalized indicators for measuring social justice in a society, but he also exposed a concept of justice (according to Rawls) in advance [69].

\subsection{Religious Education as Political Education and Character Building-The Necessity of Interdisciplinarity}

Religious education tends to challenge people to deal justly, to change unjust structures and to empower them to do justice. Knowledge and the capacity of reflection which is an insight into what is morally right, do not coercively lead to right actions. Empathy, motivation, will, and specific skills are needed as well. The concept of "compassion" as the essence of Christianity (Metz 2000) provides for conditions such as a shift of perspectives, sympathy, and the inner willingness to share suffering. If people want to take action against suffering and injustice, they have to be able to communicate in a group, to assert themselves, and to become politically active. Psychology, sociology, and pedagogy have already developed multiple interdisciplinary concepts for (religious) education of "see-judge-act" and the consideration of morality and compassion (c. e.g., [70,71]). These didactical concepts can be transferred to the topic of justice within education (c. e.g., [4] (pp. 201-219).) However, ethical reflection, as a struggle with indicating the problems and finding solutions, on concrete topics of social justice often becomes more complex. It thus must be more extensive in theory and practice than it might be when dealing with less controversial issues of individual ethics.

\section{Conclusions}

This article unfolded from an ethical point of view what has to be made explicit when Christian education and pedagogy try to educate towards justice. Firstly, teachers have to realize that, despite setting a priority on a pragmatic or poietic level, for example by establishing classroom discussions, they must be prepared to change to the theoretical level —and vice versa. They also should reflect on their presupposed, quite often more or less implicit understanding of justice. It has been shown that it is not sufficient to impose a certain understanding of e.g., social justice without good reasons and reference to an ethical approach. Besides, four dimensions of ethics can be perceived: justice in personal relations, justice as social justice, and justice as the individual and social fostering of virtue to lead a good life. Goals of teaching justice differ with regard to these dimensions, and discussions of priority-setting in education can refer to these dimensions to set realistic and precise educational goals.

Thus, education towards justice has to be well informed by philosophical or theological ethics, respectively-otherwise education tends to provide heteronomy and fundamentalism. Being able to make education goals explicit with regard to justice, and being able to identify and to defend a certain understanding of justice from an ethical point of view is a necessary precondition of Christian education towards justice for teachers and pupils.

Acknowledgments: I want to thank Anna Kohlwey for the translation of this article.

Conflicts of Interest: The author declares no conflict of interest.

\section{References}

1. Nordström, K. Autonomie und Erziehung; Karl Alber: Freiburg, Germany, 2009. (In German)

2. Mieth, D. Solidarität und Gerechtigkeit. In Solidarität und Gerechtigkeit: Die Gesellschaft von Morgen Gestalten; Mieth, D., Ed.; Katholisches Bibelwerk: Freiburg, Germany, 2009; pp. 9-18. (In German)

3. Mazouz, N. Gerechtigkeit. In Handbuch Ethik; Düwell, M., Hübenthal, C., Werner, M.H., Eds.; J.B. Metzler Verlag: Stuttgart, Germany, 2011; pp. 371-376. (In German)

4. Grümme, B. Bildungsgerechtigkeit; Kohlhammer: Stuttgart, Germany, 2014. (In German)

5. Oduaran, A.; Bhola, H.S. (Eds.) Widening Access to Education as Social Justice; Essays in Honor of Michael Omolewa; Springer: Dordrecht, The Netherlands, 2006. 
6. Zajda, J.; Majhanovic, S.; Rust, V. (Eds.) Education and Social Justice; Springer: Dordrecht, The Netherlands, 2006.

7. Autin, F.; Batruch, A.; Butera, F. Social justice in education: How the function of selection in educational institutions predicts support for (non)egalitarian assessment practices. Front. Psychol. 2015, 6, 707. [CrossRef] [PubMed]

8. Mandry, C. Gerechte Bildungschancen-Ethische Anforderungen an das deutsche Bildungssystem. In Solidarität und Gerechtigkeit; Mieth, D., Ed.; Katholisches Bibelwerk: Freiburg, Germany, 2009; pp. 237-247. (In German)

9. Ouane, A.; Glanz, C. UNESCO policies and conferences: Widening access to education to further social justice. In Widening Access to Education as Social Justice; Essays in Honor of Michael Omolewa; Oduaran, A., Bhola, H.S., Eds.; Springer: Dordrecht, The Netherlands, 2006; pp. 149-164.

10. Singh, K. Universalizing access to basic education: UNESCO's normative action. In Widening Access to Education as Social Justice; Essays in Honor of Michael Omolewa; Oduaran, A., Bhola, H.S., Eds.; Springer: Dordrecht, The Netherlands, 2006; pp. 165-192.

11. Könemann, J.; Mette, N. Bildung und Gerechtigkeit. Warum Bildung politisch sein muss. In Bildung und Gerechtigkeit; Könemann, J., Ed.; Katholisches Bibelwerk: Mainz, Germany, 2013; pp. 11-18. (In German)

12. Könemann, J. Bildungsgerechtigkeit (k)ein Thema religiöser Bildung? In Bildung und Gerechtigkeit; Könemann, J., Ed.; Katholisches Bibelwerk: Mainz, Germany, 2013; pp. 37-52. (In German)

13. Könemann, J. (Ed.) Bildung und Gerechtigkeit; Katholisches Bibelwerk: Mainz, Germany, 2013. (In German)

14. Grümme, B. Gerechtigkeit als Thema einer politisch sensiblen Religionsunterrichts. Politische Bildung 2012, 2, 104-122. (In German)

15. Neuschäfer, R. (Ed.) Gerechter Werden; Unterrichtsvorschläge, Garamond: Jena, Germany, 2010. (In German)

16. Conrad, J. Gerechtigkeit lernen! Aber wie. In Gerechtigkeit in der Bildung, Jahrbuch für Kirchliche Bildungsarbeit; Rupp, H., Ed.; Calwer: Stuttgart, Germany, 2010; pp. 126-136. (In German)

17. Schlag, T. Horizonte Demokratischer Bildung; Verlag Herder: Freiburg im Breisgau, Germany, 2010. (In German)

18. Schlag, T. Menschenrechtsbildung im Religionsunterricht. Zeitschrift für Evangelische Ethik 2011, 55, 96-110. (In German) [CrossRef]

19. Anzenbacher, A. Bildungsbegriff und Bildungspolitik. Jahrb. Christl. Sozialwiss. 1999, 40, 12-37. (In German)

20. Krause, G. (Ed.) Bildung. In Theologische Realenzyklopädie, Bd. VI; De Gruyter: Berlin, Germany, 1980; pp. 569-635. (In German)

21. Auer, A. Autonome Moral und Christlicher Glaube; Patmos-Verlag: Düsseldorf, Germany, 1971. (In German)

22. Mieth, D. Das Proprium christianum und das Menschenwürde-Argument in der Bioethik. Theologische Quartalschrift 2000, 180, 252-271. (In German)

23. Mieth, D. Ethik der Gerechtigkeit. Ansätze, Prinzipien, Kriterien. In Vision Gerechtigkeit; Mieth, D., Magino, P., Eds.; Verlag Haus Altenberg: Düsseldorf, Germany, 1992; pp. 12-32. (In German)

24. Krause, G. (Ed.) Gerechtigkeit. In Theologische Realenzyklopädie, Bd. 12; Walter de Gruyter: Berlin, Germany, 1984; pp. 404-448. (In German)

25. Betz, H.-D. (Ed.) Religion in Geschichte und Gegenwart Bd. 3; UTB: Tübingen, Germany, 2000; pp. $701-727$. (In German)

26. Gabriel, K. Gerechtigkeit. In Neues Handbuch Theologischer Grundbegriffe Bd. 1; Eicher, P., Ed.; Kösel: München, Germany, 2005; pp. 487-493. (In German)

27. Gutierrez, G. Nachfolge Jesu und Option für die Armen; Kohlhammer: Stuttgart, Germany, 2009. (In German)

28. Sobrino, J. Christologie der Befreiung Bd. 1 und 2; Matthias Grünewald Verlag: Mainz, Germany, 1998. (In German)

29. Metz, J.B. Glaube in Geschichte und Gesellschaft; Grünewald: Mainz, Germany, 1984. (In German)

30. Metz, J.B. (Ed.) Compassion. Zu einem Weltprogramm des Christentums im Zeitalter des Pluralismus der Religionen; Herder: Freiburg, Germany, 2000; pp. 9-18. (In German)

31. Schockenhoff, E. Theologie der Freiheit; Verlag Herder GmbH: Freiburg im Breisgau, Germany, 2007. (In German)

32. Bobbert, M.; Mieth, D. Das Proprium der Christlichen Ethik: Zur moralischen Perspektive der Religion; Edition Exodus: Luzern, Switzerland, 2015.

33. Gewirth, A. Reason and Morality; University of Chicago Press: Chicago, IL, USA, 1978.

34. Rawls, J. Eine Theorie der Gerechtigkeit; Suhrkamp: Frankfurt, Germany, 1975. (In German) 
35. Hobbes, T. Leviathan; Klenner, H., Ed.; Meiner: Hamburg, Germany, 1996. (In German)

36. Bentham, J. Eine Einführung in Die Prinzipien der Moral und Gesetzgebung; Höffe, O., Ed.; Verlag Senging: Tübingen, Germany, 2013; Volume 5, pp. 55-82, (Original published in 1789). (In German)

37. Nozick, R. Anarchie, Staat, Utopia, München; München Olzog: München, Germany, 2006. (In German)

38. Hödl, L. Gerechtigkeit-Mittelalter. In Theologische Realenzyklopädie Bd. XII; Walter de Gruyter: Berlin, Germany, 1984; pp. 424-432. (In German)

39. Schuwey, C.; Knöpfel, C. Neues Handbuch Armut in der Schweiz; Schweiz, C., Ed.; Caritas-Verlag: Luzern, Germany, 2014. (In German)

40. Sen, A. Ökonomie für den Menschen: Wege zur Gerechtigkeit und Solidarität in der Marktwirtschaft; dtv Verlagsgesellschaft: München, Germany, 2000. (In German)

41. Noll, H.H. (Ed.) Sozialberichterstattung in Deutschland. Konzepte, Methoden und Ergebnisse für Lebensbereiche und Bevölkerungsgruppen; Juventa-Verlag: Weinheim, Germany, 1997. (In German)

42. Haker, H. Bildung der Identität als ethische Identität. In Wann ist Bildung Gerecht? Münk, H., Ed.; Bertelsmann Publishing House: Bielefeld, Germany, 2008; pp. 113-126. (In German)

43. Höffe, O. Aristoteles; C.H. Beck: München, Germany, 1996.

44. Darling-Hammond, L. Learning to Teach for Social Justice; Darling-Hammond, L., French, J., Garcia-Lopez, S.P., Eds.; Teachers College Press: New York, NY, USA, 2002.

45. Vetter, D. Toward a critical stance: Citizenship education in the classroom. Brock Educ. 2008, 17, 87-94.

46. Elsenbast, V. (Ed.) Zur Gerechtigkeit im Bildungssystem; Waxmann: Münster, Germany, 2007. (In German)

47. Wimmer, M.; Reichenbach, R.; Pongratz, L.A. (Eds.) Gerechtigkeit und Bildung; Ferdinand Schöningh: Paderborn, Germany, 2007. (In German)

48. Heimbach-Steins, M. (Ed.) Bildung und Beteiligungsgerechtigkeit; W. Bertelsmann Publishing House: Bielefeld, Germany, 2003.

49. Heimbach-Steins, M. (Ed.) Bildungswege als Hindernisläufe; W. Bertelsmann Publishing House: Bielefeld, Germany, 2008. (In German)

50. Heimbach-Steins, M. (Ed.) Bildung, Politik und Menschenrecht; W. Bertelsmann Publishing House: Bielefeld, Germany, 2009. (In German)

51. Heinrich, M. (Ed.) Bildungsgerechtigkeit Jenseits von Chancengleichheit; Springer: Wiesbaden, Germany, 2012.

52. Frank, J. (Ed.) Heterogenität Bejahen; Waxmann: Münster, Germany, 2010. (In German)

53. Rupp, H.; Scheilke, C. (Eds.) Gerechtigkeit in der Bildung. In Jahrbuch für Kirchl; Bildungsarbeit: Stuttgart, Germany, 2010. (In German)

54. Meyer, T. (Ed.) Bildungsgerechtigkeit als Politische Aufgabe; Projekt: Freiburg, Germany, 2011. (In German)

55. Dabrowski, M. (Ed.) Bildungspolitik und Bildungsgerechtigkeit; Ferdinand Schöningh: Paderborn, Germany, 2008. (In German)

56. Beck, H.; Schmidt, H. (Eds.) Bildung als Diakonische Aufgabe; Kohlhammer: Stuttgart, Germany, 2009. (In German)

57. Bobbert, M. Zur Notwendigkeit der Rückbindung eines Autonomieprinzips an Einen Ethischen Ansatz. In Wie viel Ethik verträgt die Medizin; Düwell, M., Neumann, J.J., Eds.; Mentis: Paderborn, Germany, 2005; pp. 105-124. (In German)

58. Kant, I. Werkausgabe Bd. XII; Weischedel, W., Ed.; Suhrkamp: Frankfurt, Germany, 2000. (In German)

59. Ott, K. Moralbegründungen zur Einführung; Junius Verlag: Hamburg, Germany, 2001. (In German)

60. Mill, J.S. Der Utilitarismus; Reclam Verlag: Leipzig, Germany, 1976. (In German)

61. Höffe, O. Einführung in die Utilitaristische Ethik, 5th ed.; UTB GmbH: Tübingen, Germany, 2013. (In German)

62. Bobbert, M. Gerechtigkeit im Gesundheitswesen; Mieth, D., Ed.; Solidarität und Gerechtigkeit: Stuttgart, Germany, 2009; pp. 213-236. (In German)

63. Nida-Rümelin, J. Theoretische und angewandte Ethik; Nida-Rümelin, J., Ed.; Angewandte Ethik: Stuttgart, Germany, 2005; Volume 2, pp. 3-87. (In German)

64. Rawls, J. Ein Entscheidungsverfahren für die Normative Ethik; Birnbacher, D., Ed.; Texte zur Ethik: München, Germany, 1976; pp. 124-139, (In German). (English Original published in 1951)

65. Mieth, D. Was Wollen wir Können? Herder Verlag: Freiburg, Germany, 2002. (In German)

66. Gründel, J. Die Bedeutung der Konvergenzargumentation für die Gewißheitsbildung. In Wahrheit und Verkündigung Bd. 2; Scheffzyk, L., Ed.; Schöningh: München, Germany, 1967; pp. 1607-1630. (In German) 
67. Brot für alle; Fastenopfer. Postulat für Eine Nachhaltige Beschaffung von Computern; Brot für alle: Luzern, Switzerland, 2013.

68. Bobbert, M. Urteile in der (Bio-)Medizin und Pflegeethik Sind. "gemischte" Urteile. In Ethik in den Wissenschaften; Ammicht-Quinn, R., Ed.; IZEW (Ethik in den Wissenschaften): Tübingen, Germany, 2015; pp. 299-306. (In German)

69. Merkel, W. Soziale Gerechtigkeit und die drei Welten des Wohlfahrtskapitalismus. Berl. J. Soziol. 2001, 2, 135-157. (In German) [CrossRef]

70. Kuld, L.; Gnnheimer, S. Compassion. Sozialverpflichtendes Lernen und Handeln; Kohlhammer: Stuttgart, Germany, 2000. (In German)

71. Kuld, L.; Gönnheimer, S. Praxisbuch Compassion. Soziales Lernen an Schulen. Praktikum und Unterricht in den Sekundarstufen I und II; Auer Verlag: Augsburg, Germany, 2004. (In German)

(C) 2017 by the author. Licensee MDPI, Basel, Switzerland. This article is an open access article distributed under the terms and conditions of the Creative Commons Attribution (CC BY) license (http:/ / creativecommons.org/licenses/by/4.0/). 